\title{
Experimental hybridisation between Aphis grossulariae and Aphis triglochinis (Sternorrhyncha: Aphididae)
}

\author{
RIMANTAS RAKAUSKAS \\ Department of Zoology, Vilnius University, Čiurlionio 21/27, LT 2009 Vilnius, Lithuania; e-mail: rimantas.rakauskas@gf.vu.lt
}

Key words. Aphididae, Aphis grossulariae, Aphis triglochinis, hybridisation, systematics, currant aphids

\begin{abstract}
Aphis triglochinis and A. grossulariae clones from southern Poland produced fertile hybrid eggs under experimental conditions. Established hybrid clones expressed normal parthenogenetic reproduction but bisexual generations were obtained only in three hybrid clones out of twenty six. Fertile $\mathrm{F}_{1}$ hybrid eggs were obtained in one hybrid clone. Morphological and host-specificity features of $A$. grossulariae dominated in the majority of hybrid clones. The present results do not exclude the possibility of natural hybridisation of studied aphid species. Natural hybrids may be difficult to detect because of their "pure" morphological and hostspecificity features.
\end{abstract}

\section{INTRODUCTION}

The possibility of hybridising and producing viable and fertile progeny is an important feature of biparental species, being emphasized by the reproductive species concepts, including the biological species concept (e.g. Mayr, 1982; Dobzhansky, 1970; Paterson, 1993). Aphids are mostly biparental species, and reproductive isolation is important feature of aphid species (Shaposhnikov, 1987; Blackman, 1995; Rakauskas, 1998a). Hybridisation studies might supply important information on the taxonomic status of the forms involved in a complex (Müller, 1985; Shaposhnikov, 1987; Guldemond, 1990a; etc.), although aphid crossing experiments are rather complicated (Hales et al., 1997).

Species of the genus Aphis L. inhabiting currants in Europe [Aphis grossulariae Kaltenbach, 1843, A. triglochinis Theobald, 1926, and A. schneideri (Börner, 1940)] present certain taxonomic problems (Hille Ris Lambers \& Dicker, 1965; Stroyan, 1984; Rakauskas, 1998b). Detailed biosystematic studies of this species complex have therefore been undertaken. It appeared that the three species are rather distinct in their life-cycles and host specificity, although they share the same winter hosts. A. schneideri is monoecious holocyclic on Ribes spp., A. grossulariae is holocyclic facultatively heteroecious between Ribes spp. and Onagraceae herbs, and $A$. triglochinis is holocyclic obligatorily heteroecious between Ribes spp. and Brassicaceae, Boraginaceae and Asteraceae herbs (Rakauskas, 1993). Sibling species may occur on the summer hosts of A. triglochinis (Rakauskas, 1998b). Many of the morphological characters exploited in the keys to discriminate between the three species appeared to be unreliable. Nevertheless, morphometric analysis of numerous specimens of all morphs revealed morphological features, ensuring separation of all morphs of $A$. grossulariae, A. triglochinis and A. schneideri (Rakauskas, 1998c). All three species have the same chromosome number $(2 \mathrm{n}=8)$, and preliminary karyotype analysis suggests that $A$. triglochinis is more closely related to $A$. schneideri than to $A$. grossulariae, but this is inconsistent with morphological and host specificity data (Turčinavičienè et al., 1997). DNA-s of the three species appeared to be different when analysed by means of the randomly amplified polymorphic DNA polymerase chain reaction technique. Four out of 13 primers applied produced bands that were polymorphic among the three species. Based on the numbers of bands shared in common, $A$. grossulariae seems to be more closely related to $A$. schneideri when compared with $A$. triglochinis (Turčinavičienè et al., 1999). Thus, morphological, life-cycle, host specificity and DNA analysis data suggest that $A$. grossulariae, A. triglochinis and A. schneideri are good, well-defined species. Nevertheless, with regards to the similarity of karyotype and controversial references on the bionomics of the three species (see Rakauskas, 1998b, c), experimental interspecific hybridisation studies have been undertaken. Data on $A$. grossulariae $\times$ A schneideri and $A$. schneideri $\times A$. triglochinis crossing results are already published (Rakauskas, 1999a, b).

The aim of this work was to study the possibility of hybridisation between $A$. grossulariae and A. triglochinis under experimental conditions.

\section{MATERIAL AND METHODS}

Five clones of $A$. grossulariae and three clones of $A$. triglochinis originating from southern Poland were used for interspecific crossing experiments in Katowice (southern Poland) in 1987, each clone starting from a single fundatrix or fundatrigenia (Table 1). Hybridisation experiments were the continuation of morphological, life-cycle and host specificity studies of the two species (Rakauskas, 1993). This ensured the precise documentation of the morphology and bionomics of parental clones and provided data for obtaining key morphological characters and canonical discrimination functions to distinguish between various morphs of $A$. grossulariae and $A$. triglochinis (see below). Sixteen $A$. grossulariae $+\& \times A$. triglochinis $\delta$ and ten reciprocal crossings were tried. Ten oviparae and one male of the alternative species were isolated in muslin branch-tip cages on currant bushes for each cross. The construction of cages ensured the isolation of $10 \mathrm{~cm}$ of the terminal part of the 
TABle 1. A. grossulariae and A. triglochinis clones used for the crossing experiments in Katowice (Poland) in 1987 (c. v. - cultivated variety).

\begin{tabular}{|c|c|c|c|}
\hline Sampling locality & Sampling date & Host plant & Subsequent clone No. \\
\hline \multicolumn{4}{|c|}{ A. grossulariae } \\
\hline Katowice & May 12 & red currant c. $\mathrm{v}$. & $\mathrm{B} 1$ \\
\hline Katowice & May 12 & Ribes aureum Pursh. & E1 \\
\hline Katowice & May 12 & Ribes aureum Pursh. & $\mathrm{E} 2$ \\
\hline Katowice & May 12 & Ribes aureum Pursh. & $\mathrm{F} 1$ \\
\hline Katowice & May 23 & gooseberry c. v. & $\mathrm{F} 2$ \\
\hline \multicolumn{4}{|c|}{ A. triglochinis } \\
\hline Zabrzeg, Katowice distr. & May 18 & black currant c. $\mathrm{v}$. & A1 \\
\hline Zabrzeg, Katowice distr. & May 18 & black currant c. $v$. & $\mathrm{A} 2$ \\
\hline Katowice & July 14 & Rorippa silvestris (L.) Bess. & A3 \\
\hline
\end{tabular}

currant shoot (see Rakauskas \& Rupais, 1983). Groups of 5 to 10 gynoparae of the same clone were used to receive newly born oviparae larvae. Gynoparae were obtained from cages of clones of each respective species and their morph was confirmed under a stereoscopic microscope $(16 \times)$ before releasing them into branch-tip cages on currants. After depositing progeny gynoparae were removed and fixed in alcohol for subsequent morphological analysis, as were males. This ensured that the oviparae were virgin. It is noteworthy that $A$. grossulariae and $A$. triglochinis have no sexuparae: those remigrating from summer host plants are gynoparae producing only larvae of future oviparae. Currant shoots were isolated early in autumn, at the moment when the first gynoparae appeared, and males were not yet present. This (and careful examination of the shoot by means of $2.5 \times$ magnifying glass) eliminated the possibility of any wild eggs inside the cage. Eggs of these species have never been found in Katowice at the beginning of September.

Hybrid eggs were obtained from thirteen crosses (Table 2). Intraspecific interclonal and intraclonal crosses were also performed. Eggs were subsequently transferred (together with fragments of shoots on which they were deposited) to Vilnius (Lithuania) and maintained in field conditions throughout the winter. This was performed by attaching the fragments of the shoots containing hybrid eggs to the appropriate tip shoots of the field grown black currant bushes (mid-ripening variety "Derliai") inside muslin branch-tip cages. Currant shoots used were carefully checked using $2.5 \times$ magnifying glass, to confirm

TABLE 2. A. triglochinis and A. grossulariae successive crossings, with information on the amount of live (black shining) eggs obtained, hatching and maturation success of fundatrices and subsequent hybrid clone designation.

\begin{tabular}{|c|c|c|c|c|c|}
\hline \multirow{2}{*}{\multicolumn{2}{|c|}{$\begin{array}{l}\text { Maternal and } \\
\text { paternal clones } \\
\text { females males }\end{array}$}} & \multirow{2}{*}{\multicolumn{2}{|c|}{$\begin{array}{l}\text { No. of Hatching } \\
\text { eggs success }(\%)\end{array}$}} & \multirow{2}{*}{\multicolumn{2}{|c|}{$\begin{array}{l}\text { Fx maturation Subsequent } \\
\text { success }(\%) \text { hybrid clone }\end{array}$}} \\
\hline & & & & & \\
\hline \multicolumn{6}{|c|}{ 1. A. grossulariae $+\times$ A. triglochinis 0} \\
\hline B1 & A3 & 23 & 69.6 & 100 & $\mathrm{gt} 1-2$ \\
\hline B1 & $\mathrm{A} 1$ & 21 & 47.6 & 100 & gt3-4 \\
\hline E1 & A1 & 24 & 20.8 & 100 & $\mathrm{gt} 5-6$ \\
\hline E1 & A3 & 9 & 33.3 & 100 & gt7-8 \\
\hline E2 & A3 & 32 & 53.1 & 100 & gt9-10 \\
\hline E2 & $\mathrm{A} 1$ & 16 & 56.3 & 100 & gt11-12 \\
\hline E2 & $\mathrm{A} 2$ & 59 & 35.6 & 100 & gt13-14 \\
\hline $\mathrm{F} 2$ & $\mathrm{~A} 2$ & 68 & 45.6 & 100 & $\mathrm{gt} 15-16$ \\
\hline $\mathrm{F} 2$ & A3 & 20 & 60.0 & 100 & gt $17-20$ \\
\hline \multicolumn{6}{|c|}{ 2. A. triglochinis ㅇ $\times$ A. grossulariae ${ }^{\circ}$} \\
\hline A1 & F2 & 21 & 42.9 & 100 & $\operatorname{tg} 1-3$ \\
\hline A1 & E1 & 11 & 45.5 & 100 & $\operatorname{tg} 4-6,9-10$ \\
\hline A1 & $\mathrm{E} 2$ & 7 & 14.3 & 100 & $\operatorname{tg} 7$ \\
\hline A1 & B1 & 21 & 14.3 & 100 & $\operatorname{tg} 8$ \\
\hline
\end{tabular}

the absence of any naturally-occurring aphid eggs. The surface of the second-year currant shoot of the exploited variety is smooth, without any crannies for hidden eggs. Hatched larvae were able to crawl to bursting buds and continue their development. Hatching larvae were counted daily, as were mature fundatrices. Single fundatrices were isolated separately in branch tip muslin cages afterwards, initiating hybrid clones for subsequent morphological analysis and host specificity tests. Thus twenty six hybrid clones were started and propagated throughout 1988 in Vilnius. Rearing methods were the same as described earlier (Rakauskas, 1993). The list of clones is presented in Tables 3 and 4: clone number indicates also the origin of the hybrid clone: gt 1 means the first hybrid clone from the crossing scheme $A$. grossulariae $+\times A$. triglochinis $8, \operatorname{tg} 1-$ the first hybrid clone from the reciprocal crossing.

The fundatrix and twenty specimens (when available) of the main morphs (alatae and apterae from winter and summer hosts) of each hybrid clone were mounted in Faure-Berlese fluid on microscope slides for morphological analysis. Two methods were used for the morphological identification of hybrid clones. First, the identification was attempted using common key characters (Rakauskas, 1998c). Numbers of additional hairs on the ultimate rostral segment (for fundatrices, apterous viviparous females from currants and summer host plants, alate viviparous females from currrants, gynoparae, oviparae and males) and numbers of secondary rhinaria on the third antennal segment (for alate viviparous females from summer hosts) were used as key characters. Second, canonical variates analysis, a method that has proved very useful in distinguishing closely related aphid species (e.g., Blackman, 1992; etc.), was applied. Morphometric data of pure $A$. schneideri and $A$. grossulariae clones (see above) were used for calculating the canonical discrimination functions (CDF) for each morph. Variables used in the CDF were selected on the basis of their discriminatory power: those having the smallest partial Wilks' Lambda were taken when calculating the CDF for every morph (for details see StatSoft, 1995, Chapter 2). List of variables used for calculating the CDF for every morph is presented in Table 5. Wider information on the aphid material used has been already published (Rakauskas, $1998 \mathrm{c}$ ). The obtained CDF values were subsequently counted for every hybrid specimen of every morph, and standard box and whisker plot procedure was applied for morphological determination of various morphs of every hybrid clone. Examples illustrating the morphological identification procedure of the alate currant-inhabiting viviparous females are presented in Fig. 1 (using the key characters) and Fig. 2 (exploiting the CDF). Every morph of each hybrid clone was treated as having the morphology of a particular species if the range of the studied character or CDF values in that morph was covered by the range of the same character of that particular species. Thus, alate viviparous females (currant morph) of the hybrid clones gt6-11, 
gt15-18 were determined as having the morphology of A.grossulariae both by means of key character (Fig. 1) and CDF values (Fig. 2). The hybrid clone morph was treated as morphologically tending towards a particular species if the $25-75 \%$ box area of the studied character or CDF value of that morph was overlapped by the range of that particular species. For example, alate viviparous females (currant morphs) of hybrid clones gt3-5, gt12-14 were determined by means of key character as tending morphologically towards $A$. grossulariae (Fig. 1). The hybrid morph was treated as morphologically intermediate if the $25-75 \%$ box area of the studied character or CDF value for that morph was between the ranges of both species.

TABLE 3. Morphological and biological features of the experimental hybrid clones $(A$. grossulariae $+\times A$. triglochinis $\delta$ ) showing the summer host specificity $(+$, normal propagation on respective hosts; \pm poor propagation; - , no propagation), morphological pecularities of different morphs of each clone ( $\mathrm{fx}$ - fundatrix; apt, al - apterae and alatae from currants; aptII, alII - apterae and alatae from summer hosts; gyn gynoparae; male - males; ovip - oviparae; $\mathrm{t} \rightarrow \mathrm{t}$ - morphology as in $A$. triglochinis or tending to it; $\mathrm{g}, \rightarrow \mathrm{g}-$ morphology as in A. grossulariae or tending to it; $\mathrm{i}$ - intermediate morphological features; $\mathrm{n}$ - morph not obtained; 0 - morph obtained, but not measured) when performing identification by common key characters (key) or by means of canonical discrimination function (CDF, see in material and methods), and the overall morphology of the clone (summary). Figures in morph column - No. of analysed specimens of respective morph.

\begin{tabular}{|c|c|c|c|c|c|c|c|c|c|c|c|c|c|}
\hline \multirow[t]{2}{*}{$\begin{array}{c}\text { Clone } \\
\text { No. }\end{array}$} & \multicolumn{2}{|c|}{$\begin{array}{c}\text { Acceptance of summer } \\
\text { hosts of respective } \\
\text { species }\end{array}$} & \multicolumn{4}{|c|}{ Morphology } & \multirow[t]{2}{*}{ gt14 } & \multirow[t]{2}{*}{+} & \multirow[t]{2}{*}{-} & $\begin{array}{l}\text { aptII/n } \\
\text { allI/n } \\
\mathrm{fx} / 1\end{array}$ & $\begin{array}{l}\mathrm{n} \\
\mathrm{n} \\
\mathrm{g}\end{array}$ & $\begin{array}{l}\mathrm{n} \\
\mathrm{n} \\
\mathrm{g}\end{array}$ & \multirow[t]{2}{*}{$\mathrm{g}$} \\
\hline & grossulariae & triglochinis & Morph/No. & Key & $\mathrm{CDF}$ & Summary & & & & apt/10 & $\mathrm{g}$ & $\rightarrow \mathrm{g}$ & \\
\hline \multirow[t]{5}{*}{ gtl } & \multirow[t]{5}{*}{ \pm} & \multirow[t]{5}{*}{-} & $\mathrm{fx} / 1$ & g & $\rightarrow g$ & \multirow{5}{*}{$\rightarrow \mathrm{g}$} & & & & $\mathrm{al} / 18$ & $\rightarrow g$ & g & \\
\hline & & & apt/1 & $\mathrm{g}$ & & & & & & aptII $/ 10$ & $\rightarrow \mathrm{g}$ & $\mathrm{g}$ & \\
\hline & & & $\mathrm{al} / 7$ & $\mathrm{~g}$ & $\rightarrow \mathrm{g}$ & & & & & alII/19 & $\mathrm{g}$ & $\rightarrow \mathrm{g}$ & \\
\hline & & & aptII/0 & 0 & 0 & & gt15 & + & - & $\mathrm{fx} / 1$ & $\mathrm{~g}$ & $\mathrm{~g}$ & $\mathrm{~g}$ \\
\hline & & & $\mathrm{allI} / \mathrm{n}$ & $\mathrm{n}$ & $\mathrm{n}$ & & & & & apt $/ 5$ & g & $\mathrm{g}$ & \\
\hline \multirow[t]{5}{*}{ gt2 } & \multirow[t]{5}{*}{+} & \multirow[t]{5}{*}{-} & $\mathrm{fx} / 1$ & $\mathrm{~g}$ & $\rightarrow g$ & \multirow[t]{5}{*}{ g } & & & & $\mathrm{al} / 5$ & $\mathrm{~g}$ & $\mathrm{~g}$ & \\
\hline & & & apt $/ 4$ & $\mathrm{~g}$ & $\mathrm{~g}$ & & & & & aptII/9 & $\rightarrow g$ & $\rightarrow \mathrm{g}$ & \\
\hline & & & $\mathrm{al} / 2$ & $\mathrm{~g}$ & $\mathrm{~g}$ & & & & & alII/n & $\mathrm{n}$ & $\mathrm{n}$ & \\
\hline & & & $\operatorname{aptII} / 8$ & $g$ & $\mathrm{~g}$ & & gt16 & + & - & $\mathrm{fx} / 1$ & $\mathrm{~g}$ & $\mathrm{~g}$ & $\mathrm{~g}$ \\
\hline & & & allI/2 & $\mathrm{g}$ & $\mathrm{g}$ & & & & & apt $/ 0$ & 0 & 0 & \\
\hline \multirow[t]{5}{*}{$\mathrm{gt3}$} & \multirow[t]{5}{*}{+} & \multirow[t]{5}{*}{-} & $\mathrm{fx} / 1$ & $\mathrm{~g}$ & $\rightarrow \mathrm{g}$ & \multirow[t]{5}{*}{$\rightarrow \mathrm{g}$} & & & & $\mathrm{al} / 0$ & 0 & 0 & \\
\hline & & & apt/3 & $\rightarrow \mathrm{g}$ & $\rightarrow \mathrm{g}$ & & & & & $\operatorname{aptII} / 15$ & $\mathrm{~g}$ & $\mathrm{~g}$ & \\
\hline & & & $\mathrm{al} / 19$ & $\rightarrow \mathrm{g}$ & $\mathrm{g}$ & & & & & $\mathrm{alII} / 9$ & $\mathrm{~g}$ & $\mathrm{~g}$ & \\
\hline & & & $\mathrm{aptII} / 0$ & 0 & 0 & & gt17 & + & - & $\mathrm{fx} / 1$ & $\mathrm{~g}$ & 0 & $\mathrm{~g}$ \\
\hline & & & $\mathrm{allI} / \mathrm{n}$ & $\mathrm{n}$ & $\mathrm{n}$ & & & & & apt $/ 9$ & $\rightarrow g$ & $\mathrm{~g}$ & \\
\hline \multirow[t]{5}{*}{ gt4 } & \multirow[t]{5}{*}{+} & \multirow[t]{5}{*}{-} & $\mathrm{fx} / 1$ & $\mathrm{~g}$ & $\mathrm{~g}$ & \multirow[t]{5}{*}{$\rightarrow \mathrm{g}$} & & & & $\mathrm{al} / 16$ & $\mathrm{~g}$ & $\mathrm{~g}$ & \\
\hline & & & apt $/ 13$ & $\rightarrow \mathrm{g}$ & $\rightarrow g$ & & & & & aptII/0 & 0 & 0 & \\
\hline & & & $\mathrm{al} / 10$ & $\rightarrow \mathrm{g}$ & g & & & & & alII/0 & 0 & 0 & \\
\hline & & & aptII/18 & $\rightarrow \mathrm{g}$ & $\rightarrow \mathrm{g}$ & & & & & $\mathrm{gyn} / 2$ & $\mathrm{~g}$ & $\mathrm{~g}$ & \\
\hline & & & $\mathrm{alII} / \mathrm{n}$ & $\mathrm{n}$ & $\mathrm{n}$ & & & & & male/9 & $\mathrm{g}$ & $\rightarrow \mathrm{g}$ & \\
\hline gt5 & + & - & $\mathrm{fx} / 0$ & 0 & 0 & $g$ & & & & ovip/ 1 & $\mathrm{~g}$ & $\mathrm{i}$ & \\
\hline & & & apt $/ 12$ & g & g & & gt18 & + & - & $\mathrm{fx} / 1$ & g & g & $\mathrm{g}$ \\
\hline & & & $\mathrm{al} / 12$ & $\rightarrow \mathrm{g}$ & $\mathrm{g}$ & & & & & apt/1 & g & $\mathrm{g}$ & \\
\hline & & & $\operatorname{aptII/12}$ & g & $\mathrm{g}$ & & & & & $\mathrm{al} / 19$ & $\mathrm{~g}$ & $\mathrm{~g}$ & \\
\hline & & & $\mathrm{alII} / 18$ & $g$ & $\rightarrow \mathrm{g}$ & & & & & aptII/2 & $\mathrm{g}$ & $\mathrm{g}$ & \\
\hline & & & $\operatorname{gyn} / 2$ & $\mathrm{~g}$ & $\mathrm{~g}$ & & & & & allI $/ \mathrm{n}$ & $\mathrm{n}$ & $\mathrm{n}$ & \\
\hline & & & ovip/5 & $\mathrm{g}$ & $\mathrm{g}$ & & gt19 & \pm & - & $\mathrm{fx} / 1$ & g & $\mathrm{g}$ & $\mathrm{g}$ \\
\hline gt6 & + & - & $\mathrm{fx} / 1$ & $\mathrm{~g}$ & $\rightarrow \mathrm{g}$ & $\mathrm{g}$ & & & & apt $/ 10$ & $\rightarrow \mathrm{g}$ & $\mathrm{g}$ & \\
\hline & & & apt $/ 10$ & $\mathrm{~g}$ & g & & & & & $\mathrm{al} / 11$ & $\rightarrow \mathrm{g}$ & g & \\
\hline & & & $\mathrm{al} / 19$ & $\mathrm{~g}$ & $\mathrm{~g}$ & & & & & aptII/0 & 0 & 0 & \\
\hline & & & aptII $/ 8$ & $\rightarrow \mathrm{g}$ & $\mathrm{g}$ & & & & & alll $/ 0$ & $\mathrm{n}$ & $\mathrm{n}$ & \\
\hline & & & $\mathrm{alII} / 23$ & $\mathrm{~g}$ & $\rightarrow \mathrm{g}$ & & $\operatorname{gt} 20$ & - & - & $\mathrm{fx} / 1$ & g & $\mathrm{g}$ & $\mathrm{g}$ \\
\hline $\mathrm{gt} 8$ & \pm & - & $\mathrm{fx} / 1$ & $\mathrm{~g}$ & $\rightarrow \mathrm{g}$ & g & & & & apt $/ 6$ & g & $\rightarrow \mathrm{g}$ & \\
\hline & & & apt $/ 15$ & g & $\mathrm{g}$ & & & & & $\mathrm{al} / 1$ & g & g & \\
\hline & & & $\mathrm{al} / 9$ & g & $\mathrm{g}$ & & & & & aptll/n & $\mathrm{n}$ & $\mathrm{n}$ & \\
\hline & & & $\operatorname{aptII} / 0$ & 0 & 0 & & & & & alll/n & $\mathrm{n}$ & $\mathrm{n}$ & \\
\hline
\end{tabular}




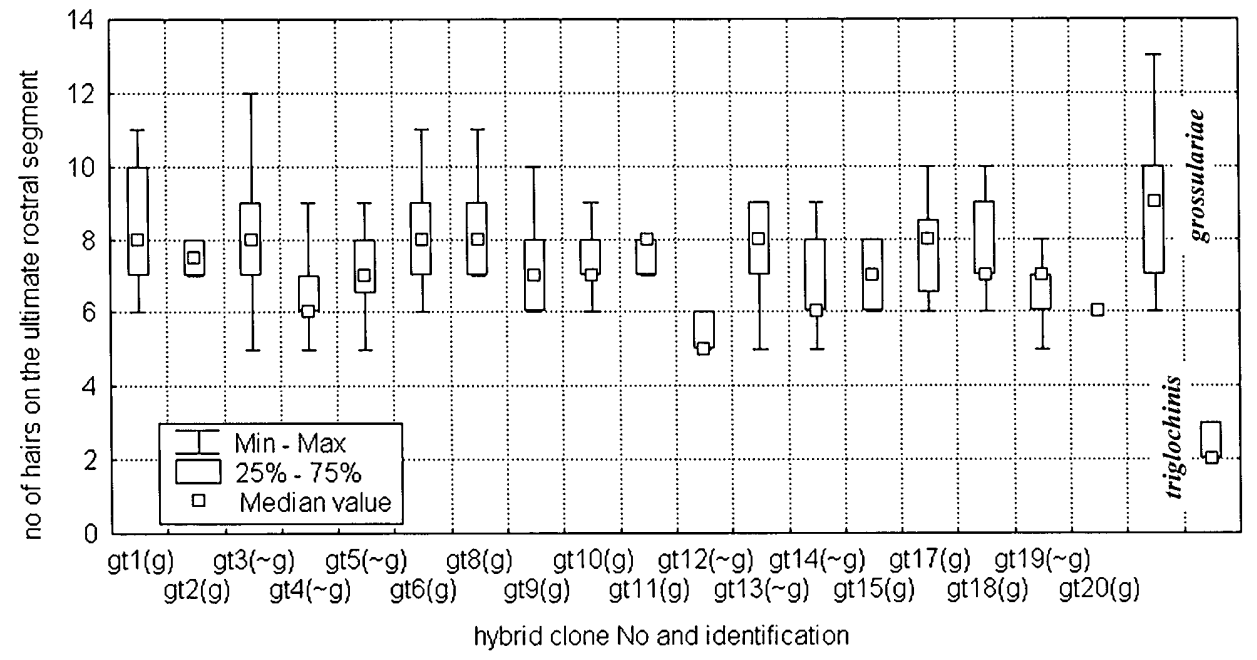

Fig. 1. Box and whisker plot of the key morphological character for the alate viviparous females of $A$. grossulariae and $A$. triglochinis and hybrid clones grossulariae $\times$ triglochinis (currant morphs).

Graphical data for other morphs of all hybrid clones (similar to those presented in Figs 1-2 for alate viviparous females) are available from the author on request. Morphological identification of fundatrices was different, because only one fundatrix of every clone was available. Scatterplot analysis procedure was performed in this case, an example being presented in Fig. 3. In total, five morphs of the majority of hybrid clones were evaluated morphologically by means of key characters and CDF Thus, ten evaluations (key characters and CDF for each morph) of every hybrid clone were obtained. Every hybrid clone was afterwards summarized as having certain overall morphological features on the basis of these ten evaluations. For example, hybrid clone gt1 (Table 3 ) had 2 evaluations (when using CDF) as tending morphologically to $A$. grossulariae, and 3 evaluations (when applying key characters) as being morphologically identical with $A$. grossulariae. In overall determination, this hybrid clone was treated as tending morphologically to A. grossulariae, since CDF performs identification on the basis of more characters. Following the same procedure, hybrid clone gt 2 was determined as morphologically identical with $A$. grossulariae, clones gt3-4 as tending morphologically to $A$. grossulariae, and so on (Tables 3-4). Discussion of morphological characters elsewhere in this paper concerns this overall morphological determination of the clone, unless otherwise stated.
All calculations were done using the STATSOFT statistical package STATISTICA for WINDOWS 5.1 (StatSoft, 1995).

Host specificity and life cycle analysis of every hybrid clone were performed in the same way as described earlier (Rakauskas, 1993). Potted Epilobium adenocaulon Hausskn., Chamaenerion angustifolium (L.) Scop. (Onagraceae, summer hosts of A. grossulariae), Cardamine amara L. (Brassicaceae) and Myosotis palustris L. (Boraginaceae; both summer hosts of $A$. triglochinis) plants were tested as potential summer hosts for every clone. Transfers of alate females were repeated (if first transfers were unsuccessful) at weekly intervals until this morph was no longer available. Groups of five migrants were used for each transfer test. This was one of the reasons for insufficient numbers of certain morphs used for the morphological analysis in some clones (e.g. lack of alate viviparae from currants in clone gt16). When only a few winged viviparae were obtained, they all were used for transfer experiments. Hybrid clones that produced sexuales were crossed both intra- and inter clonally (Table 6). Five oviparae and one male were used in each $\mathrm{F}_{1}$ crossing variant. Backcrossing with pure $A$. triglochinis and $A$. grossulariae clones was not performed because of the lack of sexuales in pure clones of these species in autumn 1988 in Vilnius.

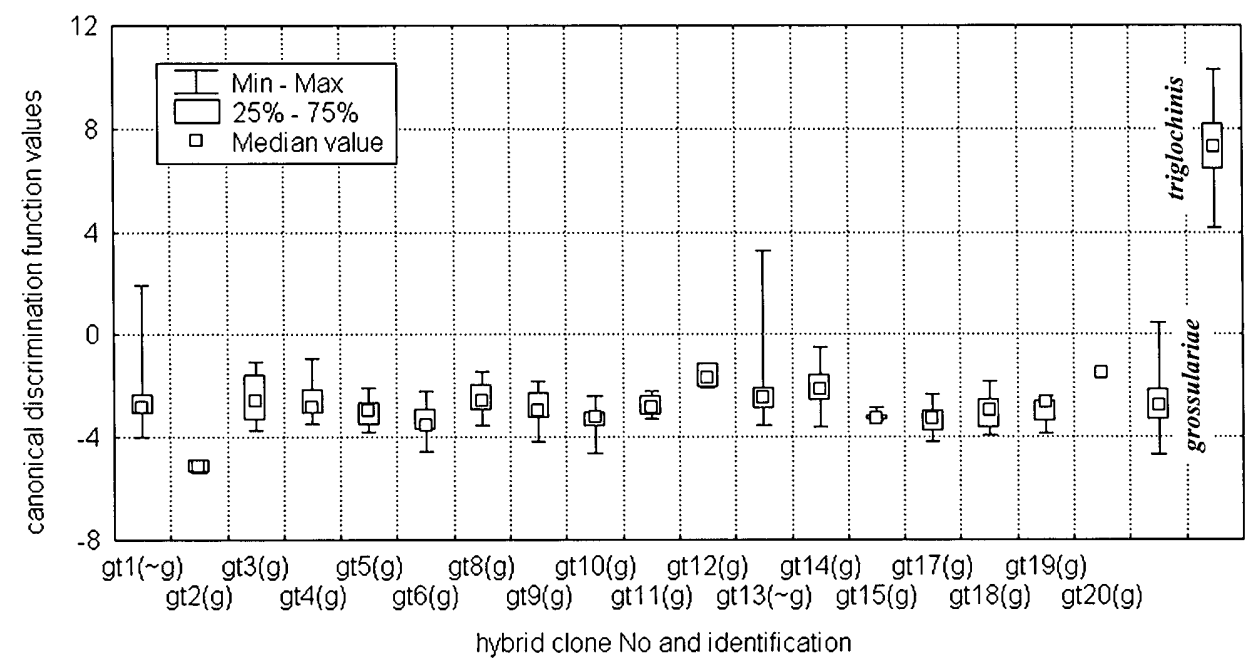

Fig. 2. Box and whisker plot of canonical discrimination function values for the alate viviparous females of $A$. grossulariae and $A$. triglochinis and hybrid clones grossulariae $\times$ triglochinis (currant morphs). 
TABLE 4. Morphological and biological features of the experimental hybrid clones (A. triglochinis $q \times A$. grossulariae $\overrightarrow{0}$ ). Abbreviations as in Table 3 .

\begin{tabular}{|c|c|c|c|c|c|c|}
\hline \multirow[t]{2}{*}{$\begin{array}{c}\text { Clone } \\
\text { No. }\end{array}$} & \multicolumn{2}{|c|}{$\begin{array}{c}\text { Acceptance of summer } \\
\text { hosts of respective } \\
\text { species }\end{array}$} & \multicolumn{4}{|c|}{ Morphology } \\
\hline & grossulariae & triglochinis & Morph/No. & Key & $\mathrm{CDF}$ & Summary \\
\hline \multirow[t]{5}{*}{$\operatorname{tg} 1$} & - & \pm & $\mathrm{fx} / 1$ & $\mathrm{t}$ & $\mathrm{t}$ & $\mathrm{t}$ \\
\hline & & & $\mathrm{apt} / \mathrm{n}$ & $\mathrm{n}$ & $\mathrm{n}$ & \\
\hline & & & $\mathrm{al} / 6$ & $\mathrm{t}$ & $\mathrm{t}$ & \\
\hline & & & $\operatorname{aptII} / \mathrm{n}$ & $\mathrm{n}$ & $\mathrm{n}$ & \\
\hline & & & $\mathrm{alll} / \mathrm{n}$ & $\mathrm{n}$ & $\mathrm{n}$ & \\
\hline \multirow[t]{5}{*}{$\operatorname{tg} 4$} & + & - & $f x / 1$ & $\mathrm{~g}$ & $\mathrm{~g}$ & $\mathrm{~g}$ \\
\hline & & & apt $/ 2$ & $\mathrm{~g}$ & $\mathrm{~g}$ & \\
\hline & & & $\mathrm{al} / 1$ & $\mathrm{~g}$ & $\mathrm{~g}$ & \\
\hline & & & aptII/0 & 0 & 0 & \\
\hline & & & alII/n & $\mathrm{n}$ & $\mathrm{n}$ & \\
\hline \multirow[t]{5}{*}{$\operatorname{tg} 5$} & \pm & - & $\mathrm{fx} / 1$ & $\mathrm{~g}$ & $g$ & $\mathrm{~g}$ \\
\hline & & & $\mathrm{apt} / 2$ & $\mathrm{~g}$ & $\mathrm{~g}$ & \\
\hline & & & $\mathrm{al} / 2$ & $\mathrm{~g}$ & $\mathrm{~g}$ & \\
\hline & & & $\operatorname{aptII} / 0$ & 0 & 0 & \\
\hline & & & alII/n & $\mathrm{n}$ & $\mathrm{n}$ & \\
\hline \multirow[t]{5}{*}{$\operatorname{tg} 6$} & $?$ & $?$ & $\mathrm{fx} / 1$ & $\mathrm{~g}$ & $\mathrm{~g}$ & $\mathrm{~g}$ \\
\hline & & & $\operatorname{apt} / \mathrm{n}$ & $\mathrm{n}$ & $\mathrm{n}$ & \\
\hline & & & $\mathrm{al} / \mathrm{n}$ & $\mathrm{n}$ & $\mathrm{n}$ & \\
\hline & & & $\operatorname{aptII} / \mathrm{n}$ & $\mathrm{n}$ & $\mathrm{n}$ & \\
\hline & & & $\mathrm{alll} / \mathrm{n}$ & $\mathrm{n}$ & $\mathrm{n}$ & \\
\hline \multirow[t]{8}{*}{$\operatorname{tg} 7$} & + & - & $\mathrm{fx} / 1$ & $\mathrm{~g}$ & $g$ & $\mathrm{~g}$ \\
\hline & & & apt $/ 5$ & $\mathrm{~g}$ & $\mathrm{~g}$ & \\
\hline & & & $\mathrm{al} / 4$ & $\mathrm{~g}$ & $\mathrm{~g}$ & \\
\hline & & & $\operatorname{aptII} / 4$ & $\mathrm{~g}$ & $\mathrm{~g}$ & \\
\hline & & & alII/1 & $\mathrm{g}$ & $\mathrm{g}$ & \\
\hline & & & $\operatorname{gyn} / 31$ & $\mathrm{~g}$ & $g$ & \\
\hline & & & male/16 & $\mathrm{g}$ & $\mathrm{g}$ & \\
\hline & & & ovip/6 & $\mathrm{g}$ & $\mathrm{g}$ & \\
\hline \multirow[t]{5}{*}{$\operatorname{tg} 8$} & \pm & - & $\mathrm{fx} / 1$ & $\mathrm{~g}$ & $\rightarrow \mathrm{g}$ & $\mathrm{g}$ \\
\hline & & & apt $/ 9$ & $\mathrm{~g}$ & $\mathrm{~g}$ & \\
\hline & & & $\mathrm{al} / 16$ & $\rightarrow \mathrm{g}$ & $\mathrm{g}$ & \\
\hline & & & $\operatorname{aptII} / 0$ & 0 & 0 & \\
\hline & & & $\mathrm{alll} / \mathrm{n}$ & $\mathrm{n}$ & $\mathrm{n}$ & \\
\hline \multirow[t]{5}{*}{$\operatorname{tg} 9$} & + & - & $\mathrm{fx} / 0$ & 0 & 0 & $\mathrm{~g}$ \\
\hline & & & apt $/ 3$ & $\mathrm{~g}$ & $\mathrm{~g}$ & \\
\hline & & & $\mathrm{al} / 10$ & $\mathrm{~g}$ & $\mathrm{~g}$ & \\
\hline & & & $\operatorname{aptII} / 8$ & $\mathrm{~g}$ & $\mathrm{~g}$ & \\
\hline & & & alIV/0 & 0 & 0 & \\
\hline
\end{tabular}

\section{RESULTS}

It seems obvious that $A$. triglochinis and $A$. grossulariae are capable of hybridising under experimental conditions: 26 hybrid clones were obtained, and they reproduced normally by means of parthenogenesis (Tables $3-4)$. On the other hand, the morphological and hostspecificity features of the hybrid clones are puzzling. Information on secondary host specificity and the morphological features of hybrid clones can be summarized as follows (overall morphological determination above the line, host specificity below the line; $\rightarrow$ gross., $\rightarrow$ trigl. overall morphology or host specificity tending to the respective species; monoec.? - hybrid clone probably monoecious on currants, rejected all proposed secondary hosts; ? - lack of information).

A. grossulariae o $\times$ A. triglochinis o crosses:

$11 \frac{\text { gross. }}{\text { gross. }}: 3 \frac{\text { gross. }}{\rightarrow \text { gross. }}: 1 \frac{\rightarrow \text { gross. }}{\rightarrow \text { gross. }}: 2 \frac{\rightarrow \text { gross }}{\text { gross. }}: 1 \frac{\text { gross. }}{?}: 1 \frac{\text { gross. }}{\text { monoec? }}$

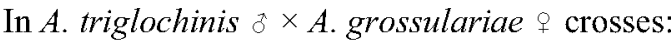

$3 \frac{\text { gross. }}{\text { gross. }}: 2 \frac{\text { gross. }}{\rightarrow \text { gross. }}: 1 \frac{\text { gross. }}{?}: 1 \frac{\text { trigl. }}{\rightarrow \text { trigl. }}$
An interesting result is that none of the 26 hybrid clones possessed intermediate morphology. 22 clones were morphologically identical with $A$. grossulariae, 3 clones tended morphologically to this species, 1 clone was identical with $A$. triglochinis. A. grossulariae morphology was dominant whether $A$. grossulariae or $A$. triglochinis oviparous females were used for the crossing experiments.

A confusing phenomenon appeared in hybrid clones gt3, gt5, gt10 and gt14: certain alate viviparous females (currant morphs) had some of the antennal hairs finely acute and relatively long (Fig. 4d). This is one of the key characters of the third currant-inhabiting species, Aphis schneideri (Fig. 4b). The existence of $A$. grossulariae specimens having $A$. schneideri-like antennal hairs has been already documented for pure clones of $A$. grossulariae (Rakauskas, 1998c).

None of the hybrid clones had the pure host specificity of A. triglochinis. Even hybrid clone tg1, being morphologically indistinguishable from A. triglochinis, developed poorly on A. triglochinis summer hosts. Alate viviparous females of this clone accepted Cardamine amara and Myosotis palustris as summer hosts, fed and deposited progeny, although no progeny reached adulthood on these plants. Alate viviparous females of this clone rejected Epilobium adenocaulon and Chamaenerion angustifolium as summer hosts. Fourteen hybrid clones normally accepted Epilobium adenocaulon and Chamaenerion angustifolium as summer hosts, eight hybrid clones propagated on these plants more poorly.

One hybrid clone (gt20, having $A$. grossulariae morphology) did not accept any of the tested herbaceous plants as summer hosts, and also failed to finish its entire life-cycle on currants. In hybrid clone gt5 (morphologically $A$. grossulariae), some gynoparae and oviparae appeared on currants, but no sexuales were produced on summer hosts. This is in accordance with the previous data on facultative heteroecy and monoecy in $\mathrm{A}$. grossulariae (Gusynina, 1963; Savzdarg \& Ponomareva, 1978).

Three hybrid clones succeeded in producing a bisexual generation. In $A$. grossulariae $+9 \times A$. triglochinis $\delta$ crossings, hybrid clone gt5 produced gynoparae and subsequently oviparae on currants. Hybrid clone gt17 gynoparae and males were produced on Epilobium adenocaulon, and oviparae (after transfer of gynoparae to winter host) on currants. In reciprocal crosses, hybrid clone $\operatorname{tg} 7$ produced plenty of gynoparae and males on Epilobium adenocaulon, and subsequently oviparae on currants. Morphologically, gynoparae and males of all three hybrid clones were similar to $A$. grossulariae (Figs 5-6). Hybrid gt5 and $\operatorname{tg} 7$ oviparae were morphologically A. grossulariae, whereas the only analysed hybrid gt17 ovipara was morphologically intermediate (Fig. 7). It is remarkable that numbers of scent plaques on the hind tibiae of hybrid oviparae were markedly reduced when compared with both parental species: in twelve analyzed hybrid oviparae, the numbers of scent plagues on the hind tibia were from 3 to 78 (mean value 33.36). The respective figures for $A$. grossulariae are 43-116 (85.00) and 


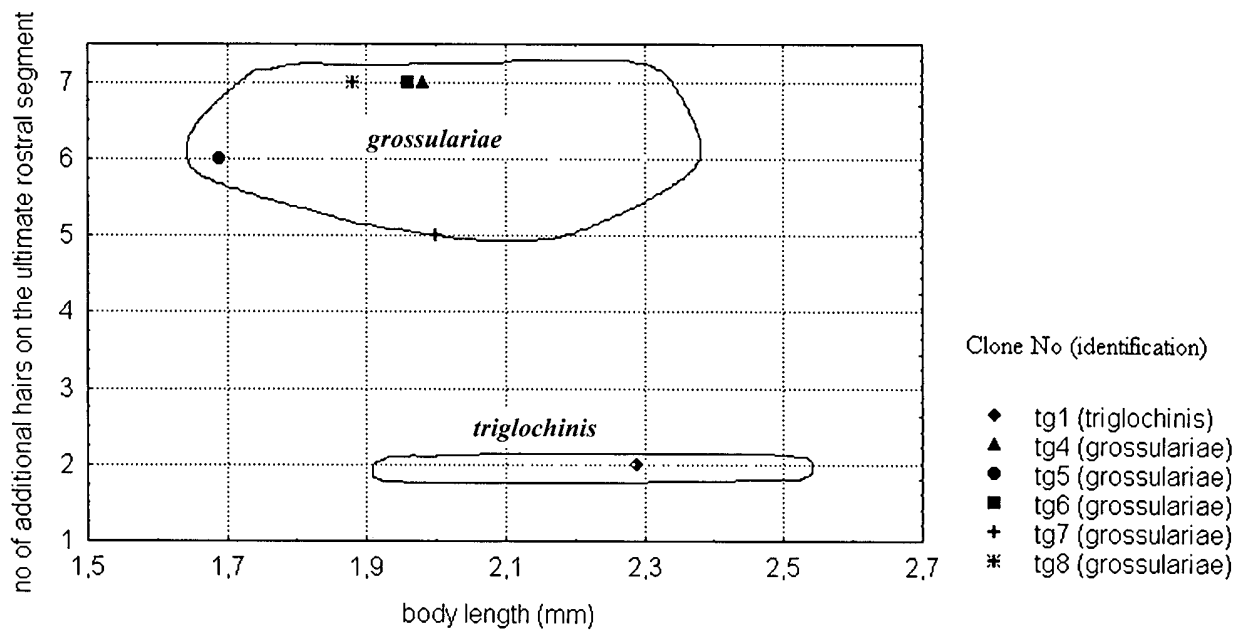

Fig. 3. Scatterplot of the individual main key character values plotted against the body length of hybrid fundatrices ( $A$. triglochinis $\times$ A. grossulariae crossings) showing the distribution of the same values in A. grossulariae and A. triglochinis fundatrices.

for A. triglochinis 56-83 (72.20). It is noteworthy that the absence of scent plagues on the hind tibiae of oviparae is characteristic of A. schneideri (Rakauskas, 1998c). The malformation of scent plagues in hybrid oviparae might explain the low success of $F_{1}$ crossing (Table 6). Intraclonal crosses of hybrid clones resulted in the appearance of winter eggs only in hybrid clones gt 5 and $\operatorname{tg} 7$, but nothing hatched from these eggs the following spring. $\mathrm{F}_{1}$ crosses with the $A$. schneideri-like hybrid clone st1 ( $A$. schneideri $\times A$. triglochinis crosses, Rakauskas, 1999b) resulted in eggs, except for the case when hybrid clone gt17 oviparae were used. Successful overwintering and hatching of these eggs occurred only in the st $1 \times \operatorname{tg} 7$ cross. Unfortunately, all five $F_{1}$ cross fundatrices were killed by an Anthocoris predatory bug (as the cage muslin was damaged) previous to their maturation. The $\mathrm{F}_{1}$ cross results suggest the possibility that hybrid $A$. grossulariae $\times$ A. triglochinis clones possessing normal potential for bisexual reproduction may be found in the field.

\section{DISCUSSION AND CONCLUSIONS}

A. triglochinis and A. grossulariae clones from southern Poland are able to produce fertile hybrid eggs under experimental conditions. Established hybrid clones expressed normal parthenogenetic reproduction, and the bisexual generation appeared in three hybrid clones. Nevertheless, $F_{1}$ crosses inside the hybrid clones were not successful. Pure clones of $A$. triglochinis and A. grossulariae also demonstrated reduced possibilities for bisexual reproduction in 1988 in Vilnius (for details, see Rakauskas, 1999a). Therefore, it remains unclear whether hybrid $A$. grossulariae $\times A$. triglochinis clones had reduced potential for bisexual reproduction and hybrid breakdown is a possible postzygotic isolating mechanism between these species. The fact that the crossing of the hybrid $A$. triglochinis $\times A$. grossulariae clone $\operatorname{tg} 7$ male with the hybrid $A$. schneideri $\times A$. triglochinis clone st1 oviparae resulted in fertile egg production supports the hypothesis of natural hybridisation between the studied species. Nevertheless, the present results are rather preliminary. Successful experimental hybridisation does not necessarily mean the possibility of natural hybridisation. Experimental interspecific crossings have been successfully performed in aphid genera Dysaphis (Shaposhnikov, 1987, etc.), Myzus (Müller, 1969), Cryptomyzus (Guldemond, 1990a, b, etc.), Ovatus (Müller \& Hubert-Dahl,

TABLE 5. Morphological characters exploited for calculating canonical discrimination functions used for the discrimination of the respective morphs of $A$. triglochinis and A. grossulariae. Abbreviations as in Table 4.

\begin{tabular}{|c|c|c|c|c|c|c|c|c|}
\hline \multirow{2}{*}{ Characters } & \multicolumn{8}{|c|}{ Morphs } \\
\hline & $f x$ & apt & al & aptII & allI & gyn & male & ovip \\
\hline Siphunculus length & & & & + & & & & \\
\hline Antennal segm. III length & & + & & & & & + & + \\
\hline Longest hair on ant. segm. III length & & & + & & & & + & \\
\hline Antennal segm. IV length & + & & & & & + & & + \\
\hline Antennal segm. $\mathrm{V}$ length & & & & & + & & & \\
\hline Basal length of ant. segm. V(VI) & & & & + & & + & & \\
\hline Processus terminalis length & + & + & + & + & + & & & + \\
\hline Articular width of ant. segm. III & + & & & & & & & \\
\hline Maximum width of ant. segm. III & & & + & & & & & \\
\hline No. of secondary rhinaria on ant. segm. III & & & + & & + & + & & \\
\hline No. of secondary rhinaria on ant. segm. IV & & & & & & + & & \\
\hline Ultimate rostral segment length & + & + & & + & & & + & \\
\hline No. of hairs on ultimate rostral segment & & + & & & & & & \\
\hline Length of cauda & & & & & & & & + \\
\hline
\end{tabular}



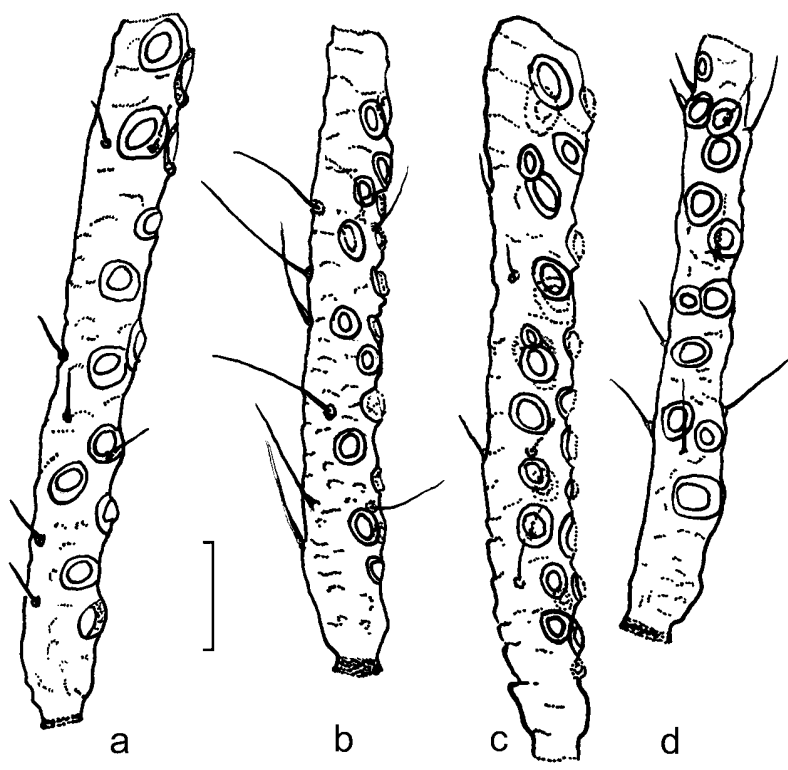

Fig. 4. Third antennal segment of alate viviparous females (currant morphs) of A. grossulariae (a), A. schneideri (b), A. triglochinis (c) and hybrid (A. grossulariae $\& \times A$. triglochinis $\left.{ }^{t}\right)$ clone gt10 (d). a - Vilnius, 26.vi.1984, cultivated red currant; b - Vilnius, 10.v.1983, cultivated red currant; c - Vilnius, 26.v.1988, cultivated black currant; d - Vilnius, 20.vi.1988, cultivated black currant. Scale: $0.05 \mathrm{~mm}$.

1979), and the Aphis fabae Scopoli complex (Müller, 1982; Thieme, 1988). Natural prezygotic isolating mechanisms might be rather sophisticated and fragile (Guldemond et al., 1994; Guldemond \& Dixon, 1994; Thieme \& Dixon, 1996), and be easily circumvented by the experimental procedure. So, information on successful experimental hybridisation reinforces the need for the study of natural isolating mechanisms between the species involved, such as sex pheromone specificity, the circadian rhythms of sex pheromone release and male activity, and other aspects of possible species-specific mate recognition systems. Crossing experiments need to be repeated with clones from other parts of the species distribution area, because the possibilities to produce hybrids may
TABle 6. Hybrid A.triglochinis x A. grossulariae $\mathrm{F}_{1}$ crossing scheme, with information on the amount of live (black shining) eggs obtained and hatching success.

\begin{tabular}{|c|c|c|c|}
\hline \multicolumn{2}{|r|}{ Maternal and paternal clones } & \multirow{2}{*}{\multicolumn{2}{|c|}{$\begin{array}{l}\text { No. of Hatching } \\
\text { eggs success }(\%)\end{array}$}} \\
\hline females & males & & \\
\hline \multicolumn{4}{|c|}{ 1. intraclonal crossings } \\
\hline gt5 & gt5 & 3 & 0 \\
\hline gt17 & gt17 & 0 & \\
\hline $\operatorname{tg} 7$ & $\operatorname{tg} 7$ & 8 & 0 \\
\hline \multicolumn{4}{|c|}{ 2. interclonal crossings } \\
\hline gt5 & st1 $($ A. schneideri $\times$ A. grossulariae $)$ & 4 & 0 \\
\hline gt17 & st1 $(A$. schneideri $\times$ A. grossulariae $)$ & 0 & \\
\hline $\operatorname{tg} 7$ & st1 $(A$. schneideri $\times$ A. grossulariae $)$ & 1 & 0 \\
\hline st1 & gt17 & 2 & 0 \\
\hline stl & $\operatorname{tg} 7$ & 9 & 55.6 \\
\hline
\end{tabular}

differ in different populations (Hewitt, 1990). DNA analysis of parental and hybrid clones (e.g. microsatellites and mitochondrial DNA techniques, see Hales et al., 1997; Sunnucks et. al., 1997) would help to confirm the identity of the crosses and indicate the degree of introgression between natural populations of this species group. The question of natural hybridisation between $A$. triglochinis and $A$. grossulariae is important not only in a taxonomic context, but also in terms of the practical needs of currant pest management. The appearance of hybrid specimens having certain morphological characters of $A$. schneideri (Fig. 4d), the third European species of the currant-inhabiting complex of the genus Aphis, is of special interest. Because of hybridisation, clones with the morphological features of $A$. grossulariae might appear, but being monoecious (as hybrid clone gt20) or facultatively monoecious (as hybrid clone gt5) on currants. This might explain previous data on monoecy in A. grossulariae (Gusynina, 1963; Savzdarg \& Ponomareva, 1978). We have recently found A. triglochinis clones in Finland that seem to be facultatively heteroecious (Rakauskas, Turčinavičienè, unpubl.), a characteristic of $A$. grossulariae.

The present data raise certain questions concerning the genetic control of morphological characters. Despite the

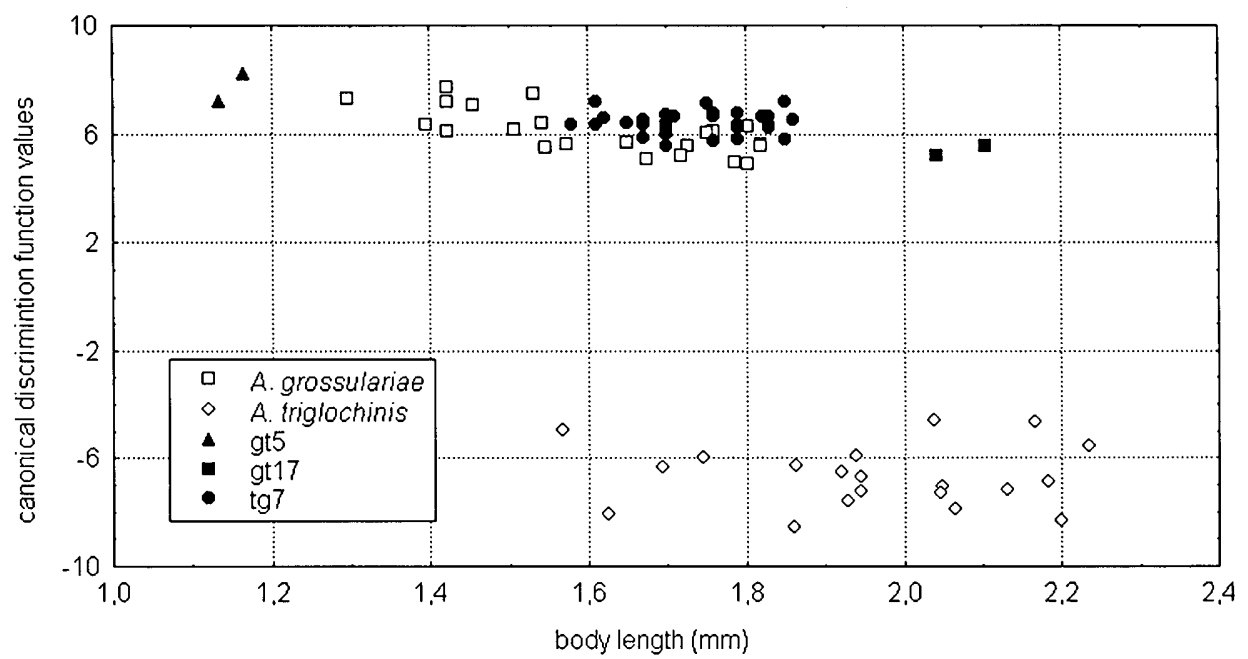

Fig. 5. Scatterplot of the individual canonical discrimination function values plotted against the body length of $A$. grossulariae, $A$. triglochinis and hybrid gynoparae. 


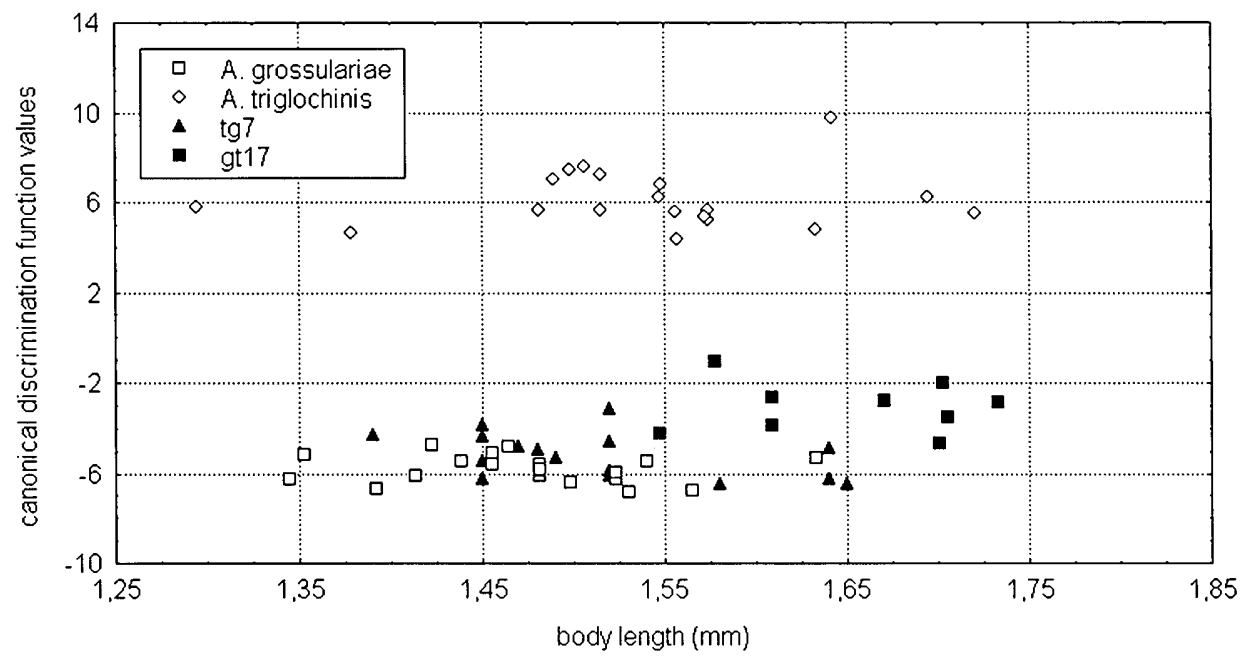

Fig. 6. Scatterplot of the individual canonical discrimination function values plotted against the body length of $A$. grossulariae, $A$. triglochinis and hybrid males.

14 characters used for calculating the CDF for the different morphs, all hybrid clones were identical with ( 23 clones of 26 ) or clearly tended to ( 3 clones) one of the species. The absence of morphologically intermediate clones is consistent with a hypothesis of the monogenic control of morphological characters, with A. grossulariae characters being dominant. That does not conform to the common understanding of the genetic control of developmental processes (Blackman, 1999, pers. comm.), although it is not absolutely impossible, e.g., the "polyphene" mutation in Drosophila affects various morphological characters, such as eyes, thorax, tarsi and wings, but it is known to be a single gene mutation (Severtsov, 1987: 24). Single gene pleiotropic effects on general morphology has been also reported in plants (Bohmert et al., 1998). The phenomenon, whereby all hybrid clones are identical with maternal species, can be explained as due to action of maternal genes (Lewin, 1996: 1141-1179), or fertilization errors, such as gynogenesis (Ham \& Veomett, 1980: 605), also due to hybridogenesis (Cherfas, 1981). Nevertheless, most of our hybrid clones that were obtained when using $A$. triglochinis oviparae (6 out of 7) were also identical with $A$. grossulariae.

The majority of hybrid clones, 22 of 26 tested, had the host specificity of $A$. grossulariae: they developed on Epilobium adenocaulon and Chamaenerion angustifolium, and rejected Cardamine amara and Myosotis palustris. The scarcity of hybrid clones having intermediate host preferences between $A$. grossulariae and $A$. triglochinis suggests monogenic control of this character. Monogenic control of host specificity has already been reported for the raspberry aphid Amphorophora rubi (Kaltenbach) (Briggs, 1965). Guldemond (1990a) also suggested that host plant specificity in the aphid genus Cryptomyzus might be controlled by only a few genes.

It may be that natural crosses between $A$. grossulariae and $A$. triglochinis (if they exist in the field) are hardly detectable, because of their similarity to one of the parental species. The dominance of morphological and host specificity features of $A$. grossulariae is in accordance with the information on the rarity of $A$. triglochinis: it is rather uncommon on currants, at least in Europe (Hille Ris Lambers \& Dicker, 1965; Cichocka, 1980;

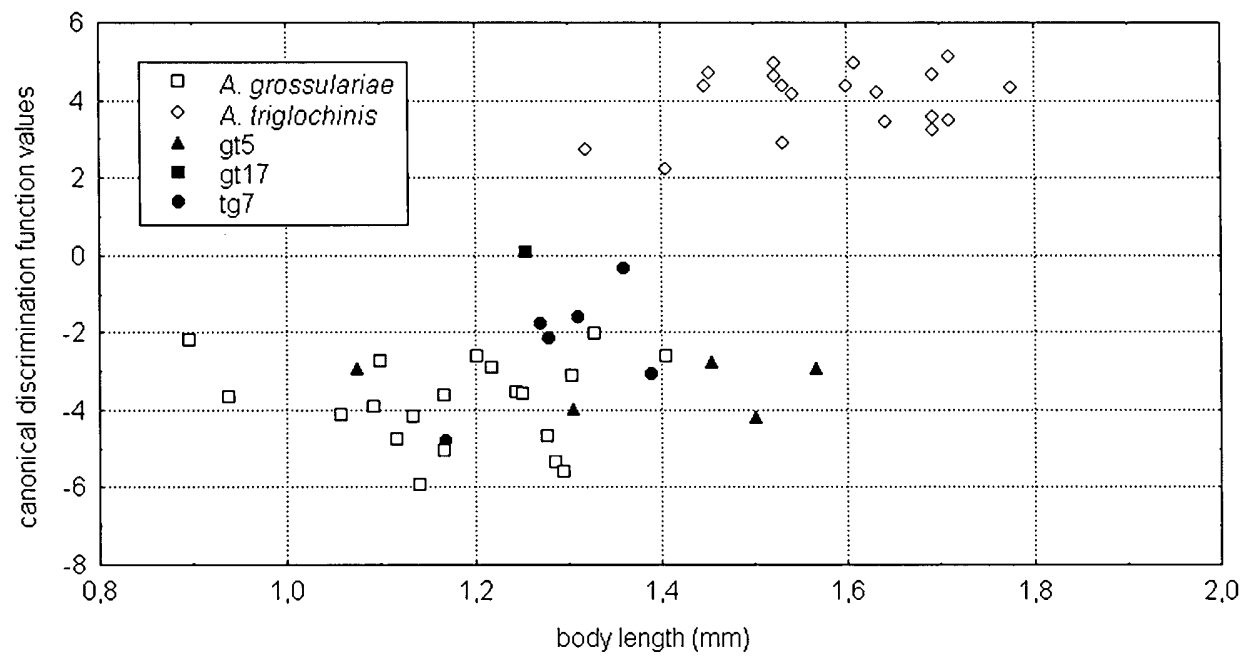

Fig. 7. Scatterplot of the individual canonical discrimination function values plotted against the body length of $A$. grossulariae, $A$. triglochinis and hybrid oviparae. 
Holman \& Pintera, 1981). A. triglochinis may be rare, if its phenotype is just a recessive homozygote of the gene, whose dominant allele causes $A$. grossulariae features. Morphology of A. schneideri, A. grossulariae and A. triglochinis suggests that the latter species should be more phylogenetically distant from the first two (Stroyan, 1984; Rakauskas, 1998c). Remaudière (1993) even places them in separate subgenera. According to this, A. grossulariae $\times A$. schneideri crosses should be more successful than $A$. grossulariae $\times A$. triglochinis, but it seems not to be true (Rakauskas, 1999a). On the other hand, the more distantly related are the parental species, the higher is probability that hybrids will look like one or the other of them. The phenomenon has been explained in other systems by preferential gene expression of the maternal allele (Wu et al., 1997), maternal gynogenesis (Makeeva, 1989), or elimination of paternal chromosomes during distant hybridogenesis (Cherfas, 1981). The explanation in the present case is not yet known.

ACKNOWLEDGEMENTS. I want to express my sincere thanks to S.-M. Klimaszewsky, W. Wojciechowsky, A. Czylok and J. Gorczyca (Katowice, Poland) for their kindness in helping to perform aphid culturing in Katowice; K. Rostanski (Katowice, Poland) and J. Tupciauskaite (Vilnius, Lithuania) for the identification of host plants; T. Wlostowski (Bialystok, Poland) for helping to perform canonical variates analysis. I express my appreciation to R. Blackman (London) for his constructive scepticism on the results of the present study. Thanks are also due to J. Lazutka (Vilnius) for reading and commenting on the manuscript.

\section{REFERENCES}

BlaCKMAN R.L. 1992: The use of ordination techniques to discriminate within pest aphid species complexes. In Sorensen J.T. \& Footit R.G. (eds): Ordination in the Study of Morphology, Evolution and Systematics of Insects. Elsevier, Amsterdam, pp. 261-275.

Blackman R.L. 1995: Species concepts and realities. Bull. Entomol. Res. 85: 1-4.

Bohmert K., Camus I., Bellint C., Bouchez D., Caboche M. \& BENNING C. 1998: AGO1 defines a novel locus of Arabidopsis controlling leaf development. EMBO Journal 17: 170-180.

BrigGs J.B. 1965: The distribution, abundance, and genetic relationships of four strains of the Rubus aphid [(Amphorophora rubi (Kalt.)] in relation to raspberry breeding. J. Hort. Sci. 40: $109-117$.

Cherfas N.B. 1981: Natural gynogenesis and hybridogenesis. In Kirpichnikov V.S. (ed): Genetic Bases of Fish Selection. Springer, Berlin-Heidelberg, pp. 255-266.

Cichocka E. 1980: Mszyce roslin sadowniczych Polski [Orchard Aphids of Poland]. State Scientific Publishers, Warszawa, 119 pp. (in Polish).

Dobzhansky T. 1970: Genetics of the Evolutionary Process. Columbia University Press, New York, 505 pp.

GULdEMOND J.A. 1990a: Evolutionary genetics of the aphid Cryptomyzus, with a preliminary analysis of the inheritance of host plant preference, reproductive performance and hostalteration. Entomol. Exp. Appl. 57: 65-76.

Guldemond J.A. 1990b: On Aphids, their Host Plants and Speciation (A Biosystematic Study of the Genus Cryptomyzus). Ponsen \& Looijen, Wageningen, $159 \mathrm{pp}$.
Guldemond J.A. \& Dixon A.F.G. 1994: Specificity and daily cycle of release of sex pheromones in aphids: a case of reinforcement? Biol. J. Linn. Soc. 52: 287-303.

Guldemond J.A., Tigges W.T. \& De VRier P.W.F. 1994: Circadian rhythm of sex pheromone production and male activity of coexisting sibling species of Cryptomyzus aphids (Homoptera: Aphididae). Eur. J. Entomol. 91: 85-89.

GusYnina L.M. 1963: [Aphids of the genus Aphis L. on currants and gooseberry.] Proc. Biol. Inst. Siberian Div. Acad. Sci. USSR 10: 77-81 (in Russian).

Hales D.F., Tomuk J., Wöhrmann K. \& Sunnucks P. 1997: Evolutionary and genetic aspects of aphid biology: A review. Eur. J. Entomol. 94: 1-55.

HaM R.G. \& VEOMetт M.J. 1980: Mechanisms of Development. C.V. Mosley, St. Louis-Toronto-London, 843 pp.

Hewitт G.M. 1990: Divergence and speciation as viewed from an insect hybrid zone. Can. J. Zool. 68: 1701-1715.

Hille Ris Lambers D. \& Dicker G.H.L. 1965: Aphis triglochinis Theobald, 1926, as a pest of red currant and black currant (Homoptera, Aphididae). Entomol. Ber. 25: 5-6.

Holman J. \& Pintera A. 1981: Übersicht der Blattlause (Homoptera, Aphidoidea) der Rumanischen Sozialistischen Republik. Studie ČSAV 15. Academia, Prague, 128 pp.

Lewin B. 1996: Genes $V$. Oxford University Press, Oxford-New York-Tokyo, $1272 \mathrm{pp}$.

MakeEva A.P. 1989: [Results of distant hybridisation of species from different families of Cypriniformes]. In Kirpichnikov V.S. (ed.): [Genetics in Aquaculture. Proceedings of 3 th AllUnion Conference of Genetics, Selection and Hybridization of Fishes]. Nauka, Leningrad, pp. 153-168 (in Russian).

MAYr E. 1982: The Growth of Biological Thought: Diversity, Evolution, and Inheritance. Harvard University Press, Cambridge, MS, $974 \mathrm{pp}$.

MưLlER F.P. 1969: Bastardierungsversuche zur Feststellung von Isolierungsmechanismen zwischen nahe verwandten Formen in der Gattung Myzus Passerini (Homoptera: Aphididae). Biol. Zbl. 88: $147-164$.

Müller F.P. 1982: Das problem Aphis fabae. Z. Angew. Entomol. 94: 432-446.

Müller F.P. 1985: Biotype Formation and Sympatric Speciation in Aphids (Homoptera: Aphidinea). Entomol. Gen. 10: 161-181.

Müller F.P. \& HuberT-Dahl M.L. 1979: Wirtwechsel, Generationenfolge und reproduktive Isolation von Ovatus crataegarius (Walker, 1850) und O. insitus (Walker, 1849). Dt. Entomol. Z. 26: 241-253.

PAterson H. 1993: Evolution and the Recognition Concept of Species: Collected Writings. Harvard University Press, Cambridge, MA, $234 \mathrm{pp}$.

Rakauskas R. 1993: On the biology of the Ribes-infesting Aphis species in Central Europe. In Kindlman P. \& Dixon A.F.G. (eds): Critical Issues in Aphid Biology. Proceedings of the 4th International Symposium on Aphids. Institute of Entomology, České Budějovice, pp. 113-122.

RAKAUSKAS R. 1998a: What is the (aphid) species? In Nieto Nafria J.M. \& Dixon A.F.G. (eds): Aphids in Natural and Managed Ecosystems. Universidad de León, León, pp. 447-451.

RAKAUSKAS R. 1998b: On the identity of Aphis triglochinis Theob. In Cichocka E., Goszczynski W. \& Wiech K. (eds): Aphids and Other Homopterous Insects 6. Polish Academy of Science, Warszawa, pp. 5-16.

RAKAUSKAS R. 1998c: Morphometric analysis of European species of the genus Aphis (Sternorrhyncha: Aphididae) inhabiting Ribes. Eur. J. Entomol. 95: 239-250. 
RaKauskas R. 1999a: Hybridisation between Aphis grossulariae and Aphis schneideri (Sternorrhyncha: Aphididae): An experimental approach. Eur. J. Entomol. 96: 401-408.

RAKAUSKAS R. 1999b: Experimental hybridisation of the currant inhabiting Palaearctic species of the genus Aphis L. (Hemiptera: Aphididae). Acta Zool. Lituan. 9(3): 96-106.

RaKaUsKas R. \& RupaIs A. 1983: Biology of the green apple aphid in Lithuania. Acta Entomol. Lituan. 6: 20-30.

REMAudière G. 1993: Pucerons nouveaux et peu connus du Mexique (12e Note) Aphis (Bursaphis) solitaria (McVicar Baker) (Homoptera, Aphididae). Rev. Fr. Entomol. (N.S.) 15: 97-106.

Savzdarg E.E. \& Ponomareva M.S. 1978: [Diagnosis of aphid species on currants and their dynamics in central districts of RSFSR.] Proc. Timirjazev Agric. Acad. 1: 150-158 (in Russian).

SEVERTSOv A.S. 1987: Fundamentals of the Theory of Evolution. Moscow University Press, Moscow, 320 pp. (in Russian).

ShaposhntKov G.Kr. 1987: Organisation (structure) of populations and species, and speciation. In Minks A.K. \& Harrewijn P. (eds): Aphids. Their Biology, Natural Enemies and Control. Vol. 2A. Elsevier, Amsterdam, pp. 415-430.

STATSOFT, INC. 1995: STATISTICA for Windows (Computer program manual). Tulsa, OK

Stroyan H.L.G. 1984: Aphids - Pterocommatinae and Aphidinae (Aphidini). Handbooks for the Identification of
British Insects. Vol. II, Part 6. Royal Entomological Society, London, $232 \mathrm{pp}$.

Sunnucks P., De Barro P.J, Lushai G., Maclean N. \& Hales D. 1997: Genetic structure of an aphid studied using microsatellites: cyclic parthenogenesis, differentiated lineages and host specialization. Mol. Ecol. 6: 1059-1073.

ThIEME T. 1988: Zur Biologie von Aphis fabae mordwilkowi Borner und Janisch, 1922 (Hom., Aphididae). J. Appl. Entomol. 105: 510-515.

Thieme T. \& Dixon A.F.G. 1996: Mate recognition in the Aphis fabae complex: daily rhythm of release and specificity of sex pheromones. Entomol. Exp. Appl. 79: 85-89.

TurČrnavičIené J., Rakauskas R. \& LazutKa J. 1997: Karyotypes of three aphid species: Aphis triglochinis, Aphis grossulariae and Aphis schneideri. Biologija (Vilnius) 4: 60-62.

TurčrnavičIené J., SužIedélis K. \& RaKaussKas R. 1999: DNA analysis of the currant inhabiting aphid species of the genus Aphis L. by means of the randomly amplified polymorphic DNA polymerase chain reaction (RAPD-PCR). Acta Zool. Lituan. 9(1): 178-182.

Wu Qinguang, Fu Hongtuo \& Ye Yuzhen 1997: Effect of enzymic gene dosage on the distant hybridisation of fishes. Acta Hydrobiol. Sin. 21: 143-151.

Received November 1, 1999; accepted January 27, 2000 